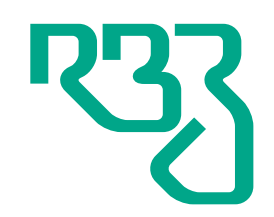

\section{Revista} Brasileira de Zootecnia

Brazilian Journal of Animal Science ISSN 1806-9290 www.rbz.org.br

\title{
Effects of varying levels of dietary protein and net energy on growth performance, nitrogen balance and faecal characteristics of growing- finishing pigs
}

\author{
Yumei Zhao ${ }^{1}$, Gang Tian ${ }^{1}$, Daiwen Chen ${ }^{1}$, Ping Zheng ${ }^{1}$, Jie $\mathrm{Yu}^{1}$, Jun $\mathrm{He}^{1}$, \\ Xiangbing $\mathrm{MaO}^{1}$, Bing $\mathrm{Yu}^{{ }^{*}}$ iD \\ ${ }^{1}$ Sichuan Agricultural University, Animal Nutrition Institute, Key Laboratory of Animal \\ Disease-Resistance Nutrition of Sichuan Province, Ya'an, Sichuan Province, Republic of \\ China.
}

\begin{abstract}
*Corresponding author: ybingtian@163.com

Received: March 11, 2018

Accepted: May 20, 2018

How to cite: Zhao, Y.; Tian, G.; Chen, D.; Zheng, P.; Yu, J.; He, J.; Mao, X. and Yu, B. 2019. Effects of varying levels of dietary protein and net energy on growth performance, nitrogen balance and faecal characteristics of growing-finishing pigs. Revista Brasileira de Zootecnia 48:e20180021. https://doi.org/10.1590/rbz4820180021
\end{abstract}

Copyright: This is an open access article distributed under the terms of the

Creative Commons Attribution License (http://creativecommons.org/licenses/by/4.0/), which permits unrestricted use, distribution, and reproduction in any medium, provided the original work is properly cited.

\begin{abstract}
This experiment was conducted to evaluate the effects of dietary protein and net energy (NE) levels on growth performance, nutrient digestibility, nitrogen metabolism, and faecal microbiota of growing-finishing pigs. Eighteen crossed barrows were randomly allocated into one of three dietary treatments: high protein + high NE diet, low protein + high NE diet, and low protein + low NE diet. The whole experiment lasted 90 days and was divided into three phases (phase I: $25-50 \mathrm{~kg}$; phase II: $50-75 \mathrm{~kg}$; phase III: 75-105 kg). All pigs were individually housed in a metabolism cage and subjected to four-day total faeces and urine collection period at the end of each phase. There was no significant difference in growth performance, nutrient digestibility, serum total protein, and albumin concentrations of pigs among the dietary treatments. Compared with the high protein + high NE diet, pigs fed low protein + high NE and low protein + low NE diets had lower $\mathrm{N}$ intake, urine $\mathrm{N}$, and total $\mathrm{N}$ excretion in each phase. At the end of the experiment, pigs fed the low protein + high NE and low protein + low $\mathrm{NE}$ diets had lower blood urea nitrogen, serum $\mathrm{NH}_{3}-\mathrm{N}$ concentrations, faecal $\mathrm{pH}$ value, faecal $\mathrm{NH}_{3}-\mathrm{N}$ concentration, and faecal Escherichia coli count than those fed the high protein + high NE diet. However, there was no significant difference in all of the above indexes between low protein + high NE and low protein + low NE diets. Decreasing the dietary protein content by 3.5 percentage units has no adverse effects on growth performance and nutrient digestibility of pigs while significantly reduces $\mathrm{N}$ excretion and faecal Escherichia coli count. Moreover, further decreasing dietary NE level in the low-protein diet by $0.35-0.5 \mathrm{MJ} / \mathrm{kg}$ does not affect growth performance, nutrient digestibility, $\mathrm{N}$ excretion, blood profiles, and faecal Escherichia coli count of pigs.
\end{abstract}

Keywords: faecal microbiota, nitrogen metabolism, nutrient digestibility, pigs

\section{(c) BY}

\section{Introduction}

Maximization of pig performance has traditionally been the goal of swine producers and nutritionists. However, over-supplementation of diets with nutrients to ensure maximum pig performance can result in an excessive amount of nutrients being excreted in the faeces and urine, ultimately into the environment, especially nitrogen (NRC, 2012). It was reported that retention of dietary $\mathrm{N}$ was only ranging from 30 to $60 \%$ of the intake of pigs, the rest were excreted in faeces and urine (Jongbloed and Lenis, 1992; Otto et al., 2003). Some previous studies confirmed that properly reducing dietary crude protein (CP) content, while maintaining adequate supplies of essential amino acids (EAA), allowed a significant reduction of total $\mathrm{N}$ excretion without any adverse effect on feed intake, growth rate, or feed 
efficiency (Dourmad et al., 1993; Kerr et al., 2003; Carpenter et al., 2004). Shriver et al. (2003) reported that decreased CP of growing pig diet from 18 to $14 \%$ supplemented with synthetic lysine, methionine, threonine, tryptophan, isoleucine, and valine had no significant effect on growth performance, while notably decreased urine $\mathrm{N}$ and total $\mathrm{N}$ emission by 40 and $50 \%$, respectively, and also markedly reduced the content of ammonia nitrogen and total volatility fatty acids of excreta. A summary of 33 swine metabolism data indicated that the total $\mathrm{N}$ excretion could be reduced by approximately $8 \%$ for each percentage unit reduction in dietary CP (but balanced for amino acid limitations) (Kerr et al., 2003).

Previous studies have shown that intake of low-protein diets increase the deposition of carcass fat in pigs; the main reason was that the amount of deamination and transamination of amino acids decreased in low protein diets fed pigs; hence, the dietary energy used for protein and AA metabolism was decreased, and more energy was deposited as fat. Besides, intake of low-protein diets decrease the weight of the visceral organs of pigs, which results in a reduction in energy requirement for maintenance and total heat production of pigs (Kerr et al., 2003); thus, more energy is used for fat deposition. Furthermore, in the case of corn-soybean meal low-protein diets, the content of CP is reduced by replacing part of the soybean meal with corn, which results in the increase of dietary NE level. Although there is similar metabolisable energy (ME) content between corn and soybean meal, net energy (NE) density of corn is higher than that of soybean meal. It has been suggested that the NE system appears to be superior to digestible energy (DE) and ME systems, which takes into account the heat consumption and energy loss via faeces, urine, and gases (Le Bellego et al., 2001; Le Bellego et al., 2002). Net energy reflects the energy requirement for animal and the dietary energy content on the same basis. Early research showed that formulation of low-protein diets using the NE system and appropriately decreased dietary NE density could improve pig carcass characteristics (Saraiva et al., 2014; Main et al., 2008; Chen et al., 2011). Protein degradation and synthesis are the processes of energy consumption. However, little information is available on the effects of reducing dietary NE density on the metabolism of protein in pigs.

Furthermore, research on low-protein diets mainly focuses on the influence on pigs themselves, but there are few studies on the effects of intestinal microbes. Diet is a key factor affecting the composition of the gut microbiota, which can serve as substrates for the fermentation of intestinal microorganisms, thereby regulating the proliferation and reproduction of microbes (Edwards, 1993).

Therefore, this study was designed to evaluate the effects of different dietary protein and NE levels on growth performance, nutrient digestibility, $\mathrm{N}$ metabolism, and faecal characteristics of growingfinishing pigs.

\section{Material and Methods}

The experimental protocols used in the current study were reviewed and approved by the Animal Care and Use Committee of Sichuan Province (case no. SYXK (Sichuan) 2014-187). The experiment was conducted in Yaan, Sichuan, China $\left(29^{\circ} 40^{\prime} \mathrm{N}\right.$ and $\left.102^{\circ} 51^{\prime} \mathrm{W}\right)$.

Eighteen crossbred barrows, (Landrace $\times$ Yorkshire) $\times$ Duroc, with initial body weight of $24.17 \pm 0.50 \mathrm{~kg}$, were blocked based on initial body weight and randomly allotted to one of three dietary treatments: high protein + high NE diet, low protein + high NE diet, and low protein + low NE diet. There were six replicates per treatment and one pig per replicate. Only barrows were selected to facilitate the collection of urine and faeces. The whole experiment lasted 90 days and was divided into three phases: phase I, 25-50 kg and lasted 35 days; phase II, 50-75 kg and lasted 28 days; and phase III, 75-105 kg and lasted 35 days). In the high protein + high NE treatment, the contents of CP and NE were 17.00$15.50-13.50 \%$ and $10.36-10.36-10.36 \mathrm{MJ} / \mathrm{kg}$ for each phase, respectively; in the low protein + high $\mathrm{NE}$ treatment, the contents of $\mathrm{CP}$ and NE were 13.50-12.00-10.00\% and 10.36-10.36-10.36 MJ/kg for each phase, respectively; in the low protein + low NE treatment, the contents of CP and NE were 13.50$12.00-10.00 \%$, and 9.86-10.01-10.01 MJ/kg for each phase, respectively. The high NE level was set according to NRC (2012), and the low NE level was adjusted according to the results of Yi et al. (2010). Experimental diets were formulated to meet or exceed the nutrient requirement recommended 
by NRC (2012), except dietary CP and NE contents (Table 1). All pigs were individually hosted in a stainless-steel metabolism cage $(1.7 \times 0.6 \times 0.7 \mathrm{~m})$ and subjected to a four-day total faeces and urine collection period at the end of each phase. Pigs were fed at 8.00,14.00, and $20.00 \mathrm{~h}$ and had free access to water.

Pigs were individually weighed on days $0,34,63$, and 90 of the experiment, and feed intake was recorded per cage every day. Average daily gain (ADG), average daily feed intake (ADFI), and feed-togain ratio ( $\mathrm{F}: \mathrm{G}$ ratio) were calculated.

During the last four days of each phase, pigs were subjected to a four-day total faeces and urine collection period. The total amount of feed intake and excreta were recorded daily. During the four-day collection period, all faeces were collected, sealed in plastic bags, weighted daily, then one-tenth of the total of faeces was sampled, followed by addition of sulfuric acid $\left(10 \% \mathrm{H}_{2} \mathrm{SO}_{4}\right)$ and two drops

Table 1 - Ingredient and chemical composition of experimental diets (as-fed basis)

\begin{tabular}{|c|c|c|c|c|c|c|c|c|c|}
\hline \multirow[b]{2}{*}{ Item } & \multicolumn{3}{|c|}{$25-50 \mathrm{~kg}$} & \multicolumn{3}{|c|}{$50-75 \mathrm{~kg}$} & \multicolumn{3}{|c|}{$75-105 \mathrm{~kg}$} \\
\hline & $\begin{array}{l}\mathrm{HCP}+ \\
\mathrm{HNE}^{5}\end{array}$ & $\begin{array}{l}\text { LCP+ } \\
\text { HNE }^{6}\end{array}$ & $\begin{array}{l}\text { LCP+ } \\
\text { LNE }^{7}\end{array}$ & $\begin{array}{l}\mathrm{HCP}+ \\
\mathrm{HNE}^{5}\end{array}$ & $\begin{array}{l}\text { LCP+ } \\
\text { HNE }^{6}\end{array}$ & $\begin{array}{l}\text { LCP+ } \\
\text { LNE }^{7}\end{array}$ & $\begin{array}{l}\mathrm{HCP}+ \\
\mathrm{HNE}^{5}\end{array}$ & $\begin{array}{l}\text { LCP+ } \\
\text { HNE }^{6}\end{array}$ & $\begin{array}{l}\text { LCP+ } \\
\text { LNE }^{7}\end{array}$ \\
\hline \multicolumn{10}{|l|}{ Ingredient ( $\mathrm{g} \mathrm{kg}^{-1} \mathrm{dry}$ matter) } \\
\hline Corn & 662.5 & 781.1 & 739.2 & 740.0 & 849.0 & 792.0 & 790.7 & 877.9 & 811.4 \\
\hline Soybean meal & 293.9 & 174.1 & 149.7 & 226.5 & 116.2 & 97.4 & 183.4 & 68.7 & 48.0 \\
\hline Wheat bran & & & 75.5 & & & 77.5 & & 22.3 & 109.4 \\
\hline Soybean oil & 18.7 & 9.7 & 0.0 & 10.0 & 1.8 & & 4.0 & & \\
\hline Limestone & 6.5 & 6.0 & 7.7 & 5.8 & 5.3 & 7.0 & 5.5 & 5.5 & 7.3 \\
\hline Monocalcium phosphate & 8.9 & 10.8 & 8.8 & 8.1 & 9.8 & 7.9 & 6.4 & 7.6 & 5.4 \\
\hline $\mathrm{NaCl}$ & 3.0 & 3.0 & 3.0 & 3.0 & 3.0 & 3.0 & 4.0 & 4.0 & 4.0 \\
\hline L-Lys-HCl (78\%) & 1.3 & 4.9 & 5.2 & 1.9 & 5.1 & 5.3 & 1.6 & 4.8 & 5.0 \\
\hline DL-Met (99\%) & 1.0 & 1.9 & 1.9 & 0.7 & 1.6 & 1.6 & 0.4 & 1.3 & 1.3 \\
\hline $\operatorname{Thr}(98.5 \%)$ & 0.5 & 1.9 & 2.1 & 0.3 & 1.7 & 1.8 & 0.3 & 1.7 & 1.8 \\
\hline $\operatorname{Trp}(98 \%)$ & & 0.5 & 0.5 & & 0.5 & 0.5 & & 0.5 & 0.5 \\
\hline Ile (99\%) & & 0.9 & 1.1 & & 0.9 & 1.1 & & 0.9 & 1.1 \\
\hline Val (99\%) & & 1.3 & 1.4 & & 1.1 & 1.1 & & 1.0 & 1.0 \\
\hline His (99\%) & & 0.2 & 0.2 & & 0.1 & 0.1 & & 0.1 & 0.2 \\
\hline Vitamin premix ${ }^{1}$ & 0.3 & 0.3 & 0.3 & 0.3 & 0.3 & 0.3 & 0.3 & 0.3 & 0.3 \\
\hline Mineral premix ${ }^{2}$ & 2.0 & 2.0 & 2.0 & 2.0 & 2.0 & 2.0 & 2.0 & 2.0 & 2.0 \\
\hline Choline chloride & 1.5 & 1.5 & 1.5 & 1.5 & 1.5 & 1.5 & 1.5 & 1.5 & 1.5 \\
\hline \multicolumn{10}{|l|}{ Nutrient } \\
\hline Crude protein ${ }^{3}$ ( $\mathrm{g} \mathrm{kg}^{-1}$ dry matter) & 170.0 & 135.0 & 135.0 & 155.0 & 120.0 & 120.0 & 135.0 & 100.0 & 100.0 \\
\hline Crude protein ${ }^{4}\left(\mathrm{~g} \mathrm{~kg}^{-1}\right.$ dry matter) & 170.4 & 137.8 & 135.1 & 154.3 & 122.0 & 121.6 & 136.2 & 103.4 & 102.0 \\
\hline Net energy $\left(\mathrm{MJ} \mathrm{kg}^{-1}\right)$ & 10.36 & 10.36 & 9.86 & 10.36 & 10.36 & 10.01 & 10.36 & 10.36 & 10.01 \\
\hline SID Lys ( $\mathrm{g} \mathrm{kg}^{-1}$ dry matter) & 9.8 & 9.8 & 9.8 & 8.5 & 8.5 & 8.5 & 7.3 & 7.3 & 7.3 \\
\hline SID (Met+Cys) ( $\mathrm{g} \mathrm{kg}^{-1}$ dry matter) & 5.5 & 5.5 & 5.5 & 4.8 & 4.8 & 4.8 & 4.2 & 4.2 & 4.2 \\
\hline SID Thr ( $\mathrm{g} \mathrm{kg}^{-1}$ dry matter) & 5.9 & 5.9 & 5.9 & 5.2 & 5.2 & 5.2 & 4.6 & 4.6 & 4.6 \\
\hline SID Trp ( $\mathrm{g} \mathrm{kg}^{-1}$ dry matter) & 1.8 & 1.7 & 1.7 & 1.5 & 1.5 & 1.5 & 1.3 & 1.3 & 1.3 \\
\hline Calcium ( $\mathrm{g} \mathrm{kg}^{-1}$ dry matter) & 6.6 & 6.6 & 6.6 & 5.9 & 5.9 & 5.9 & 5.2 & 5.2 & 5.2 \\
\hline Available phosphorous & & & & & & & & & \\
\hline ( $\mathrm{g} \mathrm{kg}^{-1}$ dry matter) & 3.4 & 3.6 & 3.4 & 3.1 & 3.4 & 3.1 & 2.7 & 2.9 & 2.5 \\
\hline
\end{tabular}

SID - standard ileal digestible; CP - crude protein; NE - net energy.

${ }^{1}$ Supplied the following per kg of diet: vitamin A, 5,512 IU; vitamin D3, 2,200 IU; vitamin E, $30 \mathrm{IU}$; vitamin K3, $2.2 \mathrm{mg}$; vitamin B12, 27.6 $\mu$ g; riboflavin, $4 \mathrm{mg}$; pantothenic acid, $14 \mathrm{mg}$; niacin, $30 \mathrm{mg}$; choline chloride, $400 \mathrm{mg}$; folic acid, $0.7 \mathrm{mg}$; thiamin, $1.5 \mathrm{mg}$; pyridoxine, $3 \mathrm{mg}$; biotin, $44 \mu \mathrm{gg}$. ${ }^{2}$ Supplied the following per kg of diet: 25-50 kg phase = Fe, $60 \mathrm{mg}$; Mn, $2 \mathrm{mg}$; Zn, $60 \mathrm{mg}$; Cu, $4 \mathrm{mg}$; I, $0.14 \mathrm{mg}$; Se, $0.2 \mathrm{mg} ; 50-75 \mathrm{~kg}$ phase = Fe, $50 \mathrm{mg}$ Mn, 2 mg; Zn, 50 mg; Cu, 3.5 mg; I, 0.14 mg ; Se, 0.15 mg; $50-75$ kg phase = Fe, 40 mg; Mn, 2 mg; Zn, 40 mg; Cu, 3.5 mg; I, 0.14 mg; Se, 0.15 mg. ${ }^{3}$ Calculated values.

${ }^{4}$ Analysed values

${ }^{5} \mathrm{High}$ protein + high NE diet $=17.0-15.5-13.5 \% \mathrm{CP}$ and $10.36 \mathrm{MJ} / \mathrm{kg}$ NE diets for phases 25-50, 50-75, and 75-105 kg, respectively.

${ }^{6}$ Low protein + high NE diet $=13.5-12.0-10.0 \% \mathrm{CP}$ and $10.36 \mathrm{MJ} / \mathrm{kg}$ NE diets for phases $25-50,50-75$, and 75-105 kg, respectively

${ }^{7}$ Low protein + low NE diet $=13.5-12.0-10.0 \% \mathrm{CP}$ and 9.86-10.01-10.01 MJ/kg NE for phases 25-50, 50-75, and 75-105 kg, respectively. 
of toluene to the sample for each pig. On the 4th day of the collection period, a few fresh faeces were sampled into a cryopreservation tube and stored at $-80{ }^{\circ} \mathrm{C}$ for further analysis. At the end of the collection period, faecal samples from each pig were pooled, and a 500-g subsample was taken, then dried in a forced-draft oven at $65^{\circ} \mathrm{C}$ and subsequently grounded through a $0.45-\mathrm{mm}$ screen. After drying and grinding, samples were kept at $-20^{\circ} \mathrm{C}$ for further analysis. Urine was collected daily at the same time as the faecal collection. At the end of the collection period, urine samples from each pig were pooled, and a $100-\mathrm{mL}$ subsample was taken and stored at $-20^{\circ} \mathrm{C}$ for further analysis.

At the end of the trial, blood samples were collected via jugular vein puncture of each pig after $12 \mathrm{~h}$ of overnight fasting. Blood samples were centrifuged $\left(3,000 \times g\right.$ for $15 \mathrm{~min}$ at $\left.4{ }^{\circ} \mathrm{C}\right)$, and serum samples were stored at $-20^{\circ} \mathrm{C}$ for blood profile analysis.

For determination of nutrient digestibility and nitrogen balance, experimental diets and faecal and urine samples were analysed in triplicate for dry matter (DM; method 930.15), ash (method 942.05), ether extract (EE; method 920.39), and crude protein (CP; method 990.03) according to AOAC (2007).

Concentrations of serum urea nitrogen (SUN), total protein (TP), albumin (ALB) were analysed using assay kits according to the manufacturer's instructions (Nanjing Jiancheng Bioengineering Institute, China). Ammonia nitrogen $\left(\mathrm{NH}_{3}-\mathrm{N}\right)$ concentration in serum and faeces was determined spectrophotometrically according to Nessler reagent with yellow colouring and photometering at a wavelength of $420 \mathrm{~nm}$.

The $\mathrm{pH}$ analysis of faeces was performed at room temperature $\left(20^{\circ} \mathrm{C}\right.$ ) with a glass electrode (model PHS-3C, INESA, Shanghai, China) directly submerged in the faecal diluent, which consisted of $1 \mathrm{~g}$ of faeces and $9 \mathrm{~mL}$ of ultrapure water.

The faecal Escherichia coli, Lactobacillus spp, and Bifidobacterium spp were determined by quantitative real-time polymerase chain reaction (PCR) as described by Diao et al. (2015). All primers and probes (Table 2) were referred by Chen et al. (2013), and commercially synthesised by Invitrogen Ltd (Shanghai, China). All measurements were determined in triplicate.

All data were compared among all three groups, being subjected to one-way ANOVA for a randomised complete block design using the SPSS statistical software package (SPSS 20.0). Statistical differences among treatments were separated by Duncan's multiple range tests. Probability values of $\mathrm{P} \leq 0.05$ were considered significant, while values of $0.05<\mathrm{P} \leq 0.10$ were considered to constitute a tendency.

Table 2 - Primers, probes, and annealed temperature for real time polymerase-chain reaction

\begin{tabular}{|c|c|c|c|}
\hline Item & Nucleotide sequence $\left(5^{\prime}-3\right.$ ') & Annealing temperature $\left({ }^{\circ} \mathrm{C}\right)$ & Product size (bp) \\
\hline \multicolumn{4}{|c|}{ Lactobacillus } \\
\hline Forward & GAGGCAGCAGTAGGGAATCTTC & 55 & 126 \\
\hline Reverse & CAACAGTTACTCTGACACCCGTTCTTC & & \\
\hline Probe & AAGAAGGGTTTCGGCTCGTAAAACTCTGTT & & \\
\hline \multicolumn{4}{|c|}{ Bifidobacterium } \\
\hline Forward & CGCGTCCGGTGTGAAAG & 53 & 121 \\
\hline Reverse & CTTCCCGATATCTACACATTCCA & & \\
\hline Probe & ATTCCACCGTTACACCGGGAA & & \\
\hline \multicolumn{4}{|c|}{ Escherichia coli } \\
\hline Forward & CATGCCGCGTGTATGAAGAA & 53 & 96 \\
\hline Reverse & CGGGTAACGTCAATGAGCAAA & & \\
\hline Probe & AGGTATTAACTTTACTCССTTCCTC & & \\
\hline
\end{tabular}




\section{Results}

Within each phase and the overall period, no significant difference was observed for ADG, ADFI, and F:G among the three dietary treatments $(P>0.05)$ (Table 3). During each phase, there were no significant differences in ATTD of DM, OM, EE, and CP among the three treatments $(\mathrm{P}>0.05)$ (Table 4).

According to the results of $\mathrm{N}$ balance (Table 5), during the 25-50 kg phase, both low protein + high $\mathrm{NE}$ and low protein + low $\mathrm{NE}$ diet groups had a lower $(\mathrm{P}<0.05) \mathrm{N}$ intake, urine $\mathrm{N}$ excretion, and total $\mathrm{N}$ excretion than that of the high protein + high NE diet group. Furthermore, pigs fed low protein + low NE diet had a lower $(\mathrm{P}<0.05)$ faecal $\mathrm{N}$ excretion than pigs fed the high protein + high $\mathrm{NE}$ diet. However, no difference was found in $\mathrm{N}$ intake, $\mathrm{N}$ excretion, and $\mathrm{N}$ retention between low protein + high $\mathrm{NE}$ and low protein + low NE diet treatments. During the 50-75 and 75-105 kg phases, N intake, urine N excretion, and total $\mathrm{N}$ excretion followed a similar pattern to that of the $25-50 \mathrm{~kg}$ phase, but no obvious difference was detected in faecal $\mathrm{N}$ excretion among the three treatments. No significant difference was observed in $\mathrm{N}$ retention rate among the three treatments during the 25-50, 50-75, and 75-105 $\mathrm{kg}$ phases.

Blood profiles of finishing pigs at the end of the experiment including BUN, $\mathrm{NH}_{3}-\mathrm{N}$, TP, and ALB were determined (Table 6). The concentrations of BUN and $\mathrm{NH}_{3}-\mathrm{N}$ were lower in pigs fed low protein + high NE and low protein + low NE diets than pigs fed high protein + high NE diet, and no significant difference was found between low protein + high NE and low protein + low NE diet groups. Serum TP and ALB contents were not affected by dietary treatments.

Table 3 - Effects of dietary treatments on growth performance of growing-finishing pigs

\begin{tabular}{|c|c|c|c|c|c|}
\hline Item & $\mathrm{HCP}+\mathrm{HNE}^{1}$ & $\mathrm{LCP}+\mathrm{HNE}^{2}$ & $\mathrm{LCP}+\mathrm{LNE}^{3}$ & SEM & P-value \\
\hline \multicolumn{6}{|l|}{ Phase I (25-50 kg) } \\
\hline Initial weight (kg) & 24.17 & 24.18 & 24.18 & 0.50 & 0.77 \\
\hline Final weight $(\mathrm{kg})$ & 52.42 & 53.08 & 51.83 & 0.67 & 0.77 \\
\hline ADFI (g) & 1659.53 & 1713.36 & 1665.74 & 32.45 & 0.78 \\
\hline ADG (g) & 807.14 & 825.95 & 790.24 & 10.00 & 0.36 \\
\hline$F: G$ & 2.06 & 2.07 & 2.11 & 0.03 & 0.84 \\
\hline \multicolumn{6}{|l|}{ Phase II (50-75 kg) } \\
\hline Initial weight (kg) & 52.42 & 53.08 & 51.83 & 0.67 & 0.77 \\
\hline Final weight $(\mathrm{kg})$ & 80.08 & 79.75 & 77.75 & 1.09 & 0.67 \\
\hline ADFI (g) & 2666.69 & 2704.10 & 2642.64 & 47.06 & 0.88 \\
\hline ADG (g) & 988.09 & 952.38 & 925.60 & 20.17 & 0.47 \\
\hline$F: G$ & 2.71 & 2.85 & 2.88 & 0.06 & 0.49 \\
\hline \multicolumn{6}{|l|}{ Phase III (75-105 kg) } \\
\hline Initial weight (kg) & 80.08 & 79.75 & 77.75 & 1.09 & 0.67 \\
\hline Final weight $(\mathrm{kg})$ & 105.75 & 105.08 & 104.48 & 1.42 & 0.94 \\
\hline ADFI (g) & 3165.83 & 3289.67 & 3223.67 & 71.51 & 0.80 \\
\hline ADG (g) & 950.62 & 938.27 & 990.13 & 30.43 & 0.79 \\
\hline$F: G$ & 3.44 & 3.52 & 3.25 & 0.11 & 0.63 \\
\hline \multicolumn{6}{|l|}{ Overall (25-105 kg) } \\
\hline Initial weight (kg) & 24.17 & 24.18 & 24.18 & 0.50 & 1.00 \\
\hline Final weight $(\mathrm{kg})$ & 105.75 & 105.08 & 104.48 & 1.42 & 0.94 \\
\hline ADFI (g) & 2424.76 & 2494.48 & 2437.07 & 39.88 & 0.77 \\
\hline $\mathrm{ADG}(\mathrm{g})$ & 906.48 & 898.98 & 892.32 & 13.80 & 0.93 \\
\hline $\mathrm{F}: \mathrm{G}$ & 2.69 & 2.78 & 2.73 & 0.04 & 0.83 \\
\hline
\end{tabular}

SEM - standard error of the mean $(n=6$, number of replicates); ADFI - average daily feed intake; ADG - average daily gain; F:G - feed to gain ratio; $\mathrm{CP}$ - crude protein; NE - net energy.

${ }^{1}$ High protein + high NE diet $=17.0-15.5-13.5 \%$ CP and $10.36 \mathrm{MJ} / \mathrm{kg}$ NE diets for phases I, II, and III, respectively.

${ }^{2}$ Low protein + high NE diet $=13.5-12.0-10.0 \% \mathrm{CP}$ and $10.36 \mathrm{MJ} / \mathrm{kg} \mathrm{NE}$ diets for phases I, II, and III, respectively.

${ }^{3}$ Low protein + low NE diet $=13.5-12.0-10.0 \% \mathrm{CP}$ and 9.86-10.01-10.01 MJ/kg NE for phases I, II, and III, respectively. 
Table 4 - Effects of dietary treatments on apparent total tract digestibility of nutrients of growing-finishing pigs (\%)

\begin{tabular}{|c|c|c|c|c|c|}
\hline Item & $\mathrm{HCP}+\mathrm{HNE}^{1}$ & $\mathrm{LCP}+\mathrm{HNE}^{2}$ & $\mathrm{LCP}+\mathrm{LNE}^{3}$ & SEM & P-value \\
\hline \multicolumn{6}{|c|}{ Phase I (25-50 kg) } \\
\hline Dry matter & 87.00 & 87.38 & 87.15 & 0.39 & 0.93 \\
\hline Crude protein & 84.33 & 84.71 & 84.55 & 0.55 & 0.96 \\
\hline Ether extract & 71.19 & 74.49 & 75.26 & 1.07 & 0.34 \\
\hline Dry matter & 86.24 & 86.66 & 86.43 & 0.31 & 0.88 \\
\hline Organic matter & 88.91 & 89.14 & 88.88 & 0.25 & 0.91 \\
\hline Crude protein & 84.63 & 82.30 & 84.66 & 0.63 & 0.31 \\
\hline Ether extract & 60.95 & 58.38 & 57.40 & 1.03 & 0.37 \\
\hline Crude protein & 83.99 & 84.01 & 84.69 & 0.50 & 0.83 \\
\hline Ether extract & 57.73 & 53.46 & 54.44 & 0.93 & 0.12 \\
\hline
\end{tabular}

SEM - standard error of the mean ( $n=6$, number of replicates); CP - crude protein; NE - net energy.

${ }^{1}$ High protein + high NE diet $=17.0-15.5-13.5 \% \mathrm{CP}$ and $10.36 \mathrm{MJ} / \mathrm{kg}$ NE diets for phases I, II, and III, respectively.

${ }^{2}$ Low protein + high NE diet $=13.5-12.0-10.0 \% \mathrm{CP}$ and $10.36 \mathrm{MJ} / \mathrm{kg} \mathrm{NE}$ diets for phases I, II, and III, respectively.

${ }^{3}$ Low protein + low NE diet $=13.5-12.0-10.0 \% \mathrm{CP}$ and $9.86-10.01-10.01 \mathrm{MJ} / \mathrm{kg} \mathrm{NE}$ for phases I, II, and III, respectively.

Table 5 - Effects of dietary treatments on N retention and excretion of growing-finishing pigs

\begin{tabular}{|c|c|c|c|c|c|}
\hline Item & $\mathrm{HCP}+\mathrm{HNE}^{1}$ & $\mathrm{LCP}+\mathrm{HNE}^{2}$ & $\mathrm{LCP}+\mathrm{LNE}^{3}$ & SEM & P-value \\
\hline \multicolumn{6}{|l|}{ Phase I (25-50 kg) } \\
\hline $\mathrm{N}$ intake (g/day) & $61.20 \mathrm{a}$ & $51.35 b$ & $47.42 b$ & 1.76 & $<0.01$ \\
\hline Fecal N excreted (g/day) & $10.41 \mathrm{a}$ & $8.88 \mathrm{ab}$ & $8.24 b$ & 0.39 & 0.05 \\
\hline Urine $\mathrm{N}$ excreted (g/day) & $10.17 \mathrm{a}$ & $5.55 \mathrm{~b}$ & $5.40 \mathrm{~b}$ & 0.90 & 0.04 \\
\hline Total $\mathrm{N}$ excretion (g/day) & $20.58 \mathrm{a}$ & $14.42 \mathrm{~b}$ & $13.64 b$ & 1.18 & 0.02 \\
\hline Retained N (g/day) & $40.62 \mathrm{a}$ & $36.93 a b$ & $33.77 \mathrm{~b}$ & 1.11 & 0.03 \\
\hline $\mathrm{N}$ retention rate $(\%)$ & 66.71 & 72.02 & 71.00 & 1.42 & 0.28 \\
\hline \multicolumn{6}{|l|}{ Phase II (50-75 kg) } \\
\hline $\mathrm{N}$ intake (g/day) & $75.46 a$ & $61.96 \mathrm{~b}$ & $58.97 \mathrm{~b}$ & 2.29 & $<0.01$ \\
\hline Fecal N excreted (g/day) & 11.11 & 9.84 & 9.41 & 0.44 & 0.28 \\
\hline Urine $\mathrm{N}$ excreted (g/day) & $14.43 a$ & $10.79 b$ & $10.46 \mathrm{~b}$ & 0.76 & 0.04 \\
\hline Total $\mathrm{N}$ excretion (g/day) & $25.54 \mathrm{a}$ & $20.63 b$ & $19.86 \mathrm{~b}$ & 1.00 & 0.03 \\
\hline Retained N (g/day) & $49.92 \mathrm{a}$ & $41.33 b$ & $39.11 b$ & 1.89 & 0.03 \\
\hline $\mathrm{N}$ retention rate $(\%)$ & 65.92 & 66.33 & 66.25 & 1.19 & 0.98 \\
\hline \multicolumn{6}{|l|}{ Phase III (75-105 kg) } \\
\hline $\mathrm{N}$ intake (g/day) & $71.45 \mathrm{a}$ & $59.48 b$ & $59.16 b$ & 2.42 & 0.05 \\
\hline Fecal N excreted (g/day) & 12.00 & 9.71 & 9.94 & 0.53 & 0.15 \\
\hline Urine $\mathrm{N}$ excreted (g/day) & $15.19 \mathrm{a}$ & $11.54 \mathrm{~b}$ & $11.41 b$ & 0.73 & 0.04 \\
\hline Total N excretion (g/day) & $27.19 a$ & $21.26 \mathrm{~b}$ & $21.35 b$ & 1.11 & 0.03 \\
\hline Retained N (g/day) & 44.26 & 38.23 & 37.81 & 2.16 & 0.42 \\
\hline $\mathrm{N}$ retention rate (\%) & 60.81 & 64.00 & 63.92 & 1.69 & 0.71 \\
\hline
\end{tabular}

SEM - standard error of the mean $(n=6$, number of replicates); CP - crude protein; NE - net energy.

${ }^{1}$ High protein + high NE diet $=17.0-15.5-13.5 \% \mathrm{CP}$ and $10.36 \mathrm{MJ} / \mathrm{kg}$ NE diets for phases I, II, and III, respectively.

${ }^{2}$ Low protein + high NE diet $=13.5-12.0-10.0 \% \mathrm{CP}$ and $10.36 \mathrm{MJ} / \mathrm{kg} \mathrm{NE}$ diets for phases I, II, and III, respectively.

${ }^{3}$ Low protein + low NE diet $=13.5-12.0-10.0 \% \mathrm{CP}$ and $9.86-10.01-10.01 \mathrm{MJ} / \mathrm{kg} \mathrm{NE}$ for phases I, II, and III, respectively.

$\mathrm{a}-\mathrm{b}$ - Values with different letters in the same row are different $(\mathrm{P}<0.05)$. 
Faecal $\mathrm{NH}_{3}-\mathrm{N}$ concentration and $\mathrm{pH}$ value were also determined (Table 7). During each phase, pigs fed the low protein + high $\mathrm{NE}$ and low protein + low $\mathrm{NE}$ diets had a lower $(\mathrm{P}<0.05)$ faecal $\mathrm{NH}_{3}-\mathrm{N}$ concentration than those fed the high protein + high NE diet. At the same time, the faecal $\mathrm{pH}$ value of pigs fed low protein + high NE diet was lower $(\mathrm{P}<0.05)$ than that pigs fed high protein + high NE diet during the 25-50 and 75-100 kg phases. Within each phase, no difference was detected in faecal $\mathrm{pH}$ value between low protein + high NE and low protein + low NE groups.

From the results of the faecal microbiota of finishing pigs at the end of the experiment (Table 8), it was found that based on the same dietary NE density, reduced CP level had no significant impact on faecal Lactobacillus counts. However, the population of faecal Bifidobacterium of pigs fed the low protein + high $\mathrm{NE}$ diet tended to increase $(\mathrm{P}=0.07)$ when compared with pigs fed the high protein +

Table 6 - Effects of dietary treatments on blood profiles of finishing pigs

\begin{tabular}{|c|c|c|c|c|c|}
\hline Item & $\mathrm{HCP}+\mathrm{HNE}^{1}$ & $\mathrm{LCP}+\mathrm{HNE}^{2}$ & $\mathrm{LCP}+\mathrm{LNE}^{3}$ & SEM & P-value \\
\hline BUN (mmol/L) & $4.92 \mathrm{a}$ & $3.44 \mathrm{~b}$ & $3.22 \mathrm{~b}$ & 0.22 & $<0.01$ \\
\hline $\mathrm{TP}(\mathrm{g} / \mathrm{L})$ & 58.13 & 60.55 & 58.10 & 1.07 & 0.59 \\
\hline ALB $(g / L)$ & 41.32 & 44.89 & 41.80 & 0.90 & 0.23 \\
\hline $\mathrm{NH}_{3}-\mathrm{N}(\mathrm{mg} / \mathrm{L})$ & $53.34 \mathrm{a}$ & $47.36 \mathrm{~b}$ & $48.33 \mathrm{~b}$ & 1.02 & 0.02 \\
\hline
\end{tabular}

BUN - serum urea nitrogen; TP - total protein; ALB - albumin; SEM - standard error of the mean ( $n=6$, number of replicates); CP - crude protein; NE - net energy.

${ }^{1}$ High protein + high NE diet $=17.0-15.5-13.5 \% \mathrm{CP}$ and $10.36 \mathrm{MJ} / \mathrm{kg}$ NE diets for phases I, II, and III, respectively.

${ }^{2}$ Low protein + high NE diet $=13.5-12.0-10.0 \% \mathrm{CP}$ and $10.36 \mathrm{MJ} / \mathrm{kg} \mathrm{NE}$ diets for phases I, II, and III, respectively.

${ }^{3}$ Low protein + low NE diet $=13.5-12.0-10.0 \%$ CP and 9.86-10.01-10.01 MJ $/ \mathrm{kg} \mathrm{NE}$ for phases I, II, and III, respectively.

$\mathrm{a}-\mathrm{b}$ - Values with different letters in the same row are different $(\mathrm{P}<0.05)$.

Table 7 - Effects of dietary treatments on faecal $\mathrm{pH}$ value and $\mathrm{NH}_{3}-\mathrm{N}$ concentration of pigs

\begin{tabular}{|c|c|c|c|c|c|}
\hline Item & $\mathrm{HCP}+\mathrm{HNE}^{1}$ & $\mathrm{LCP}+\mathrm{HNE}^{2}$ & $\mathrm{LCP}+\mathrm{LNE}^{3}$ & SEM & P-value \\
\hline \multicolumn{6}{|c|}{ Phase I (25-50 kg) } \\
\hline $\mathrm{NH}_{3}-\mathrm{N}(\mathrm{mg} / \mathrm{g})$ & $1339.42 \mathrm{a}$ & $941.34 \mathrm{~b}$ & $911.76 b$ & 72.59 & 0.02 \\
\hline $\mathrm{pH}$ & $6.73 a$ & $6.27 \mathrm{~b}$ & $6.49 \mathrm{ab}$ & 0.07 & 0.01 \\
\hline \multicolumn{6}{|c|}{ Phase II (50-75 kg) } \\
\hline $\mathrm{NH}_{3}-\mathrm{N}(\mathrm{mg} / \mathrm{g})$ & $1197.66 a$ & $823.57 b$ & $731.88 b$ & 77.06 & 0.02 \\
\hline $\mathrm{pH}$ & $6.91 \mathrm{a}$ & $6.59 \mathrm{ab}$ & $6.42 \mathrm{~b}$ & 0.08 & 0.01 \\
\hline \multicolumn{6}{|c|}{ Phase III (75-105 kg) } \\
\hline $\mathrm{NH}_{3}-\mathrm{N}(\mathrm{mg} / \mathrm{g})$ & $1163.32 \mathrm{a}$ & $665.68 \mathrm{~b}$ & $672.32 \mathrm{~b}$ & 3.03 & $<0.01$ \\
\hline $\mathrm{pH}$ & $6.91 \mathrm{a}$ & $6.70 \mathrm{~b}$ & $6.55 \mathrm{~b}$ & 0.05 & $<0.01$ \\
\hline
\end{tabular}

SEM - standard error of the mean ( $n=6$, number of replicates); CP - crude protein; NE - net energy.

${ }^{1}$ High protein + high NE diet $=17.0-15.5-13.5 \% \mathrm{CP}$ and $10.36 \mathrm{MJ} / \mathrm{kg}$ NE diets for phases I, II, and III, respectively.

${ }^{2}$ Low protein + high NE diet $=13.5-12.0-10.0 \% \mathrm{CP}$ and $10.36 \mathrm{MJ} / \mathrm{kg} \mathrm{NE}$ diets for phases I, II, and III, respectively.

${ }^{3}$ Low protein + low NE diet $=13.5-12.0-10.0 \% \mathrm{CP}$ and 9.86-10.01-10.01 MJ/kg NE for phases I, II, and III, respectively.

$\mathrm{a}-\mathrm{b}$ - Values with different letters in the same row are different $(\mathrm{P}<0.05)$.

Table 8 - Effects of dietary treatments on faecal Lactobacillus, Bifidobacterium, and Escherichia coli counts of finishing pigs

\begin{tabular}{lccccc}
\hline Item & HCP+HNE & LCP+HNE & LCP+LNE & SEM & P-value \\
\hline Lactobacillus $(\log [$ copies/g]) & 7.54 & 7.88 & 7.50 & 0.14 & 0.12 \\
Bifidobacterium $(\log [$ copies/g]) & 8.68 & 9.48 & 9.58 & 0.18 & 0.07 \\
Escherichia coli $(\log [$ copies/g]) & $9.11 \mathrm{a}$ & $8.38 \mathrm{~b}$ & $8.35 \mathrm{~b}$ & 0.14 & 0.03 \\
\hline
\end{tabular}

SEM - standard error of the mean $(n=6$, number of replicates); CP - crude protein; NE - net energy.

${ }^{1}$ High protein + high NE diet $=17.0-15.5-13.5 \% \mathrm{CP}$ and $10.36 \mathrm{MJ} / \mathrm{kg}$ NE diets for phases I, II, and III, respectively.

${ }^{2}$ Low protein + high NE diet $=13.5-12.0-10.0 \% \mathrm{CP}$ and $10.36 \mathrm{MJ} / \mathrm{kg} \mathrm{NE}$ diets for phases I, II, and III, respectively.

${ }^{3}$ Low protein + low NE diet $=13.5-12.0-10.0 \%$ CP and 9.86-10.01-10.01 MJ/kg NE for phases I, II, and III, respectively.

$\mathrm{a}-\mathrm{b}$ - Values with different letters in the same row are different $(\mathrm{P}<0.05)$. 
high NE diet. Decrease of dietary CP level led to a significant decrease in faecal Escherichia coli counts of pigs $(\mathrm{P}<0.05)$. There was no difference in populations of faecal Lactobacillus, Bifidobacterium, and Escherichia coli between low protein + high NE and low protein + low NE groups.

\section{Discussion}

There is growing environmental awareness on animal production due to the increasingly negative impact of animal production on the environment (Portejoie et al., 2002). Traditionally, oversupplementation of diets with nutrients to ensure the maximisation of pig performance can result in an excessive amount of nutrients being excreted in the faeces and urine. Nitrogen is one of the primary sources of environmental pollution caused by livestock manure. Level of dietary CP may affect water intake and subsequent excretion and manure output. Furthermore, most of the $\mathrm{N}$ loss is related to the low efficiency of digestion and absorption of N source (Otto et al., 2003). Pigs fed low CP diets supplemented with crystalline AA have been shown to achieve the same performance as those fed normal CP level diets (Kerr et al., 2003; Shriver et al., 2003; Deng et al., 2007), while the amount of N excretion was reduced dramatically. Growth response of pigs fed reduced CP diets varies among the results of published studies (Figueroa et al., 2003; Shrive et al., 2003; Knowles et al., 1998); usually, a reduction of four percentage points or less of CP supplement with AA did not hamper growth performance (Figueroa et al., 2002; Kerr et al., 2003). In the current study, reduced CP level by 3.5 percentage points had no difference in growth performance, which was consistent with previous studies (Figueroa et al., 2002; Kerr et al., 2003). For growing-finishing pigs, growth performance and lean tissue deposition will not be influenced if crystalline AA is provided to balance any dietary AA limitation, because the essence of protein nutrition is to meet the needs of amino acids of growing-finishing pigs.

Reducing dietary CP level will result in a decrease in protein and AA deamination, urea excretion, and heat production of pigs (Noblet et al., 2001). Furthermore, the weight of viscera associated with protein metabolism is reduced for pigs that received low CP diets (Kerr et al., 2003; De La Llata et al., 2007). Size of viscera and energy intake were positively correlated; viscera accounted for only $10 \%$ of body weight, but the total calories consumed was more than 50\% (Gómez et al., 2002). Protein has a higher heat increment than that of carbohydrate and fat (Noblet et al., 1994). Consequently, low CP diets will save more dietary energy, which could increase fat deposition, but lead to a negative effect on carcass quality. Previous research has shown that formulation of low-protein diets using NE system and appropriately decreasing dietary NE density could regulate pig carcass fat deposition (Kerr et al., 2003; De La Llata et al., 2007). However, protein degradation and synthesis are processes that consume energy. Thus, different dietary energy levels would affect nitrogen deposition and emission. However, in the present study, we found that, based on the same low dietary CP level, decreasing dietary NE density by $0.5,0.35$, and $0.35 \mathrm{MJ} / \mathrm{kg}$ for the $25-50,50-75$, and $75-105 \mathrm{~kg}$ phases, respectively, had no effect on growth performance, which was consistent with previous studies (Knowles et al., 1998; Kerr et al., 2003).

It is well known that energy density is the first determinant of ADFI in most instances (Henry, 1985). However, most studies have assumed that, over a wide range of dietary energy density, pigs will adjust feed intake to maintain a constant or nearly constant daily energy intake (Ellis and Augspurger, 2001). It is noteworthy that the result of Yi et al. (2010) showed that there was a significant increase first and then a decrease in ADG as the NE level of the low-protein diet decreased. On the other hand, Quiniou et al. (1995) reported a significant increase in ADG as the NE level of the low-protein diet increased.

The inconsistent results on ADFI and ADG may be associated with different levels of NE in various studies. Pigs must be supplied with adequate levels of energy, which should be in an optimum ratio to dietary protein content, to maximise growth performance and lean deposition. The relationship between energy intake and tissue growth is that lean tissue and growth rate respond linearly to energy intake up to a point where the protein deposition rate is at a maximum. Any additional energy supplied beyond this point will result in a huge increase in lipid deposition with a modest rise in lean tissue (Lunen et al., 2001). In the research of Yi et al. (2010), the appropriate NE level was within the dietary

R. Bras. Zootec., 48:e20180021, 2019 
NE levels set by the test; however, Quiniou et al. (1995) could not find the appropriate NE level within the NE levels set by their trial.

In the current study, the low dietary NE level was based on the adequate NE level of Yi et al. (2010). The range from low to a high level was narrow $(0.35-0.5 \mathrm{MJ} / \mathrm{kg})$; thus, there was no noticeable difference in ADG between the low protein + high NE and low protein + low NE diets.

It was reported that nutrient digestibility of pigs fed reduced CP diets was varied depending on the extent of $\mathrm{CP}$ reduction, the number of indispensable AA supplemented, and the energy level of the diets. In the current study, reduced CP level had no significant effect on the ATTD of DM, OM, CP, and EE. Similar results were also observed by Kerr et al. (2003), who reported that there was no difference in $\mathrm{N}$ digestibility and crude fat digestibility between pigs fed a $16 \% \mathrm{CP}$ and $12 \% \mathrm{CP}$ diet. However, the results of Noblet et al. (1987) showed an increase in N digestibility as dietary CP levels increased. In contrast, Jin et al. (1998) reported that feeding a low CP diet with supplemental crystalline AA could improve CP and DM digestibility compared with feeding a high CP diet. There is no simple linear relationship between nutrient digestibility and protein content in the feed. De Silva and Perera (1984) pointed out that the apparent digestibility of protein increased first and then declined in the continued increase of feed protein content. At the same time, in the present study, dietary NE density also did not influence the ATTD of DM, OM, CP, and EE.

Formulation of reduced CP diets and supplementation with synthetic AA may mitigate the environmental impact of swine production by reducing $N$ excretion (Dourmad et al., 1993; Kerr, 2003). In the current study, we found that within each growth period, decreased dietary CP level dramatically reduced $\mathrm{N}$ intake, urine $\mathrm{N}$ excretion, and total $\mathrm{N}$ (faecal + urine) excretion. As a result, it can be calculated that the total $\mathrm{N}$ excretion of low protein + high $\mathrm{NE}$ and low protein + low NE groups decreased by 23.17 and $25.13 \%$ in the whole experimental period, respectively, when compared with that of the high protein + high NE group. This was in good agreement with previous reports (Dourmad et al., 1993; Kerr, 2003), which indicated that for each percentage point reduction in dietary CP combined with AA supplementation, the total $\mathrm{N}$ excretion (urinary $\mathrm{N}+$ faecal $\mathrm{N}$ ) was reduced by approximately $8 \%$. Decreasing dietary NE density by $0.5,0.35$, and $0.35 \mathrm{MJ} / \mathrm{kg}$ for the $25-50,50-75$, and $75-105 \mathrm{~kg}$ phases, respectively, did not affect $\mathrm{N}$ excretion and $\mathrm{N}$ retention in low-protein diet. Nitrogen retention or $\mathrm{N}$ balance reflects the utilisation of proteins and balance between the body protein synthesis and degradation. The balance between dietary protein and energy affects the deposition and utilisation of protein (Campbell and Taverner, 1988). Only with the sufficient dietary energy, reducing the protein level could decrease $\mathrm{N}$ emissions, as protein metabolism is quite active and consume much energy; if the energy intake is lower than the requirement of maximum $\mathrm{N}$ deposition, $\mathrm{N}$ excretion in the urine will increase, while the biological value of $\mathrm{N}$ will decrease (Close, 1996). The result of the current study indicated that decreasing dietary NE density by $0.35-0.5 \mathrm{MJ} / \mathrm{kg}$ during the whole experiment could meet the energy requirement of the protein metabolism and utilisation when pigs fed a low-protein diet.

The contents of serum TP and ALB reflect the level of protein in the diet and the degree of digestion, absorption, and utilisation of protein by the animal. The concentration of BUN was affected by the quantity and quality of dietary protein and the dietary amino acid balance condition. There was a significant negative correlation between the content of BUN and the utilization rate of protein or amino acid (Coma et al., 1995). Ammonia nitrogen is the product of intestinal microbiota-fermented protein and amino acid that also can reflect the utilisation of protein and AA. In the present study, there was no difference in serum TP and ALB concentration among the three treatments. However, pigs fed the low protein + high NE diet had a significantly lower serum BUN concentration and serum $\mathrm{NH}_{3}-\mathrm{N}$ concentration than pigs fed the high protein + high NE diet. This result is consistent with previous research (Figueroa et al., 2003; Kerr et al., 2003). It indicated that degradation of protein and amino acids were reduced when pigs fed low CP diet. However, decreased dietary NE density in low CP diet did not affect serum BUN and $\mathrm{NH}_{3}-\mathrm{N}$ concentrations. 
Concentration of $\mathrm{NH}_{3}-\mathrm{N}$ in the excrement reflects the presence of $\mathrm{N}$ in the form of free ammonia $\left(\mathrm{NH}_{3}\right)$ and ammonium $\left(\mathrm{NH}_{4}^{+}\right)$. During the discharge and storage process, 50 to $75 \%$ of the $\mathrm{N}$ in the excrement would decompose to $\mathrm{NH}_{3}-\mathrm{N}$ by urease (Aarnink and Verstegen, 2007). Urease is a cytoplasmic enzyme primarily presented in faeces and feed, whose activity is affected by optimum $\mathrm{pH}$ value ranging from 6 to 9 . When $\mathrm{pH}<7, \mathrm{NH}_{3}-\mathrm{N}$ is mainly in the form of $\mathrm{NH}_{4}^{+}$; when $\mathrm{pH}>7, \mathrm{NH}_{3}$ begins to be produced; when $\mathrm{pH} \geq 9.25$, the vast majority of $\mathrm{NH}_{3}-\mathrm{N}$ separate into $\mathrm{NH}_{3}$. It is essential to maintain $\mathrm{NH}_{3}-\mathrm{N}$ in the $\mathrm{NH}_{4}^{+}$state, because $\mathrm{NH}_{3}$ would be difficult to control once released into the air. Emission of $\mathrm{NH}_{3}$ was reduced by approximately $45 \%$ for one-point reduction in slurry $\mathrm{pH}$ (Canh et al., 1998). In the current study, pigs fed low $\mathrm{CP}$ diet had a lower faecal $\mathrm{NH}_{3}-\mathrm{N}$ concentration and $\mathrm{pH}$ value, which was consistent with the studies of Portejoie et al. (2004). The result was caused by less protein fermented in the hind gut and lower acid-binding capacity of low protein ingredients. However, decreasing the dietary NE density in low CP diet had no significant impact on faecal $\mathrm{NH}_{3}-\mathrm{N}$ concentration and $\mathrm{pH}$ value. It is suggested that decreasing dietary NE density by $0.35-0.5 \mathrm{MJ} / \mathrm{kg}$ did not affect the digestion of protein in the foregut.

In the current study, we found that pigs fed the low-protein diet had a smaller population of faecal Escherichia coli, which corroborates Opapeju et al. (2009). Escherichia coli has a strong ability to hydrolyse and ferment proteins, which has a competitive advantage over other bacteria in amino acid-rich environments and can use AA as an energy source (Wellock et al., 2006; Rist et al., 2014). Meanwhile, low protein diet has a lower acid-binding capacity; the lower $\mathrm{pH}$ environments inhibited the proliferation of Escherichia coli. However, the faecal Bifidobacterium counts of pigs tended to increase by decreased dietary CP content. Bifidobacterium has the ability to degrade polysaccharides; the amount of Bifidobacterium in feaces depends on the content of carbohydrates in the diet (Mikkelsen and Jensen, 2004), and the low pH environment is beneficial to the proliferation of Bifidobacterium. In the present study, to reduce the dietary protein levels, the proportion of soybean meal in the formulation was reduced and the ratio of corn was increased. At the same time, wheat bran was used to replace partial corn to reduce dietary NE density. Therefore, the proportion of corn or wheat bran in the low-protein diet was higher than that of the high-protein diet. Pigs fed the low-protein diets would have more resistant starch or non-starch polysaccharide entered into the hindgut and utilised by microbiota. Therefore, more carbohydrates in the low-protein diets promoted the increase of the faecal Bifidobacterium count.

\section{Conclusions}

Reducing dietary crude protein level by 3.5 percentage points does not affect the growth performance of growing-finishing pigs, but drastically reduces $\mathrm{N}$ excretion and faecal Escherichia coli count. Additionally, decreasing net energy density of low protein diets by $0.50,0.35$, and $0.35 \mathrm{MJ} / \mathrm{kg}$ for the 25-50, 50-75, and 75-105 kg phases, respectively, has no significant effect on growth performance, $\mathrm{N}$ balance, blood profiles, and faecal bacteria population. Therefore, from the perspectives of animal production and environmental protection, it is feasible to formulate a low-protein diet with appropriately decreased dietary net energy level for growing-finishing pigs.

\section{Acknowledgments}

This study was supported by the Grant from the Science and Technology Support Program of Sichuan Province (2015NZ0042, 2016NZ006).

\section{References}

Aarnink, A. J. A. and Verstegen, M. W. A. 2007. Nutrition, key factor to reduce environmental load from pig production. Livestock Science 109:194-203. https://doi.org/10.1016/j.livsci.2007.01.112

AOAC - Association of Official Analytical Chemists. 2007. Official methods of analysis of the Association of Official Analytical Chemists International. 18th ed. Gaithersburg, MD, USA. 
Campbell, R. G. and Taverner, M. R. 1988. Relationships between energy intake and protein and energy metabolism, growth and body composition of pigs kept at 14 or $32^{\circ} \mathrm{C}$ from 9 to $20 \mathrm{~kg}$. Livestock Production Science 18:289-303. https://doi.org/10.1016/0301-6226(88)90037-1

Canh, T. T.; Aarnink, A. J.; Verstegen, M. W. and Schrama, J. W. 1998. Influence of dietary factors on the pH and ammonia emission of slurry from growing-finishing pigs. Journal of Animal Science 76:1123-1130.

Carpenter, D. A.; O'Mara, F. P. and O'Doherty, J. V. 2004. The effect of dietary crude protein concentration on growth performance, carcass composition and nitrogen excretion in entire grower-finisher pigs. Irish Journal of Agricultural and Food Research 43:227-236.

Chen, H.; Mao, X. B.; He, J.; Yu, B.; Huang, Z. Q.; Yu, J.; Zheng, P. and Chen, D. W. 2013. Dietary fibre affects intestinal mucosal barrier function and regulates intestinal bacteria in weaning piglets. The British Journal of Nutrition 110:1837-1848. https://doi.org/10.1017/S0007114513001293

Chen, H. Y.; Yi, X. W.; Zhang, G. J.; Lu, N.; Chu, L. C.; Thacker, P. A. and Qiao, S. Y. 2011. Studies on reducing nitrogen excretion: I. Net energy requirement of finishing pigs maximizing performance and carcass quality fed low crude protein diets supplemented with crystalline amino acids. Journal of Animal Science and Biotechnology 2:84-93

Close, W. H. 1996. Modelling the growing pig: Predicting nutrient needs and responses. p.289-297. In: Biotechnology in the feed industry. The living gut: Bridging the gap between nutrition and performance. Lyons, T. P. and Jacques, K. A., eds. Proceedings of the Alltech's 12th Annual Symposium. Nottingham University Press, Nottingham, UK.

Coma, J.; Zimmerman, D. R. and Carrion, D. 1995. Relationship of rate of lean tissue growth and other factors to concentration of urea in plasma of pigs. Journal of Animal Science 73:3649-3656.

De La Llata, M.; Dritz, S. S.; Tokach, M. D.; Goodband, R. D. and Nelssen, J. L. 2007. Effects of increasing lysine to calorie ratio and added fat for growing-finishing pigs reared in a commercial environment: I. Growth performance and carcass characteristics. The Professional Animal Scientist 23:417-428. https://doi.org/10.15232/S1080-7446(15)30997-9

De Silva, S. S. and Perera, M. K. 1984. Digestibility in Sarotherodon niloticus fry: effects of dietary protein level and salinity with further observations on variability in daily digestibility. Aquaculture 38:293-306. https://doi.org/10.1016/00448486(84)90334-X

Deng, D.; Li, A. K.; Chu, W. Y.; Huang, R. L.; Li,T. J.; Kong, X. F.; Liu, Z. J.; Wu, G. Y.; Zhang, Y. M. and Yin, Y. L. 2007. Growth performance and metabolic responses in barrows fed low-protein diets supplemented with essential amino acids. Livestock Science 109:224-227. https://doi.org/10.1016/j.livsci.2007.01.104

Diao, H.; Zheng, P.; Yu, B.; He, J.; Mao, X. B.; Yu, J. and Chen, D. W. 2015. Effects of benzoic acid and thymol on growth performance and gut characteristics of weaned piglets. Asian-Australasian Journal of Animal Sciences 28:827-839. https://doi.org/10.5713/ajas.14.0704

Dourmad, J. Y.; Henry, Y.; Bourdon, D.; Quiniou, N. and Guillou, D. 1993. Effect of growth potential and dietary protein input on growth performance, carcass characteristics and nitrogen output in growing-finishing pigs. p.206-211. In: Verstegen, M. W. A.; den Hartog, L. A.; Kempen, G. J. M. and Metz, J. H. M., eds. Nitrogen flow in pig production and environmental consequences: Proceedings of the 1st Int. Symp. Wageningen, Netherlands.

Edwards, C. 1993. Interactions between nutrition and the intestinal microflora. Proceedings of the Nutrition Society 52:375-382.

Ellis, M. and Augspurger, N. 2001. Feed intake in growing-finishing pigs. p.447-467. In: Swine nutrition. Lewis, A. J.; Southern, L. L., eds. CRC Press, Boca Raton, Florida.

Figueroa, J. L.; Lewis, A. J.; Miller, P. S.; Fischer, R. L. and Diedrichsen, R. M. 2003. Growth, carcass traits, and plasma amino acid concentrations of gilts fed low-protein diets supplemented with amino acids including histidine, isoleucine, and valine. Journal of Animal Science 81:1529-1537.

Figueroa, J. L.; Lewis, A. J.; Miller, P. S.; Fischer, R. L.; Gómez, R. S. and Diedrichsen, R. M. 2002. Nitrogen metabolism and growth performance of gilts fed standard corn-soybean meal diets or low-crude protein, amino acid-supplemented diets. Journal of Animal Science 80:2911-2919. https://doi.org/10.2527/2002.80112911x

Gómez, R. S.; Lewis, A. J.; Miller, P. S.; Chen, H. Y. and Diedrichsen, R. M. 2002. Body composition and tissue accretion rates of barrows fed corn-soybean meal diets or low-protein, amino acid-supplemented diets at different feeding levels. Journal of Animal Science 80:654-662. https://doi.org/10.2527/2002.803654x

Henry, Y. 1985. Dietary factors involved in feed intake regulation in growing pigs: A review. Livestock Production Science 12:339-354. https://doi.org/10.1016/0301-6226(85)90133-2

Jin, C. F.; Kim, J. H.; Han, I. K. and Bae, S. H. 1998. Effects of supplemental synthetic amino acids to the low protein diets on the performance of growing pigs. Asian-Australasian Journal of Animal Sciences 11:1-7. https://doi.org/10.5713/ ajas.1998.1

Jongbloed, A. W. and Lenis, N. P. 1992. Alteration of nutrition as a means to reduce environmental pollution by pigs. Livestock Production Science 31:75-94. https://doi.org/10.1016/0301-6226(92)90057-B

Kerr, B. J. 2003. Dietary manipulation to reduce environmental impact. p.139-158. In: 9th International Symposium on Digestive Physiology in Pigs. Banff, Alberta, Canada.

R. Bras. Zootec., 48:e20180021, 2019 
Kerr, B. J.; Yen, J. T.; Nienaber, J. A. and Easter, R. A. 2003. Influences of dietary protein level, amino acid supplementation and environmental temperature on performance, body composition, organ weights and total heat production of growing pigs. Journal of Animal Science 81:1998-2007. https://doi.org/10.2527/2003.8181998x

Knowles, T. A.; Southern, L. L.; Bidner, T. D.; Kerr, B. J. and Friesen, K. G. 1998. Effect of dietary fiber or fat in low-crude protein, crystalline amino acid-supplemented diets for finishing pigs. Journal of Animal Science 76:2818-2832.

Le Bellego, L.; Van Milgen, J.; Dubois, S. and Noblet, J. 2001. Energy utilization of low-protein diets in growing pigs. Journal of Animal Science 79:1259-1271. https://doi.org/10.2527/2001.7951259x

Le Bellego, L.; Van Milgen, J. and Noblet, J. 2002. Effect of high temperature and low-protein diets on the performance of growing-finishing pigs. Journal of Animal Science 80:691-701. https://doi.org/10.2527/2002.803691x

Lunen, T. A. V.; Cole, D. J. A.; Garnsworthy, P. C. and Wiseman, J. 2001. Energy-amino acid interactions in modern pig genotypes. p.439-466. In: Recent developments in pig nutrition 3. Wiseman, J.; Garnsworthy, P. C., eds. Nottingham University Press, Leicestershire, UK.

Main, R. G.; Dritz, S. S.; Tokach, M. D.; Goodband, R. D. and Nelssen, J. L. 2008. Determining an optimum lysine:calorie ratio for barrows and gilts in a commercial finishing facility. Journal of Animal Science 86:2190-2207. https://doi. org/10.2527/jas.2007-0408

Mikkelsen, L. L. and Jensen, B. B. 2004. Effect of fructo-oligosaccharides and transgalacto-oligosaccharides on microbial populations and microbial activity in the gastrointestinal tract of piglets post-weaning. Animal Feed Science and Technology 117:107-119. https://doi.org/10.1016/j.anifeedsci.2004.07.015

NRC - National Research Council. 2012. Committee on Nutrient Requirements of Swine. Nutrient requirements of swine. 11th ed. National Academy Press, Washington, DC.

Noblet, J.; Le Bellego, L.; Van Milgen, J. and Dubois, S. 2001. Effects of reduced dietary protein level and fat addition on heat production and nitrogen and energy balance in growing pigs. Animal Research 50:227-238. https://doi.org/10.1051/ animres:2001129

Noblet, J.; Henry, Y. and Dubois, S. 1987. Effect of protein and lysine levels in the diet on body gain composition and energy utilization in growing pigs. Journal of Animal Science 65:717-726.

Noblet, J.; Shi, X. S. and Dubois, S. 1994. Effect of body weight on net energy value of feeds for growing pigs. Journal of Animal Science 72:648-657. https://doi.org/10.2527/1994.723648x

Opapeju, F. O.; Krause, D. O.; Payne, R. L.; Rademacher, M. and Nyachoti, C. M. 2009. Effect of dietary protein level on growth performance, indicators of enteric health, and gastrointestinal microbial ecology of weaned pigs induced with postweaning colibacillosis. Journal of Animal Science 87:2635-2643. https://doi.org/10.2527/jas.2008-1310

Otto, E. R.; Yokoyama, M.; Ku, P. K.; Ames, N. K. and Trottier, N. L. 2003. Nitrogen balance and ileal amino acid digestibility in growing pigs fed diets reduced in protein concentration. Journal of Animal Science 81:1743-1753. https://doi org/10.2527/2003.8171743x

Portejoie, S.; Martinez, J. and Landmann, G. 2002. Ammonia of farm origin: impact on human and animal health and on the natural habitat. Productions Animales 15:151-160.

Portejoie, S.; Dourmad, J. Y.; Martinez, J. and Lebreton, Y. 2004. Effect of lowering dietary crude protein on nitrogen excretion, manure composition and ammonia emission from fattening pigs. Livestock Production Science 91:45-55. https://doi.org/10.1016/j.livprodsci.2004.06.013

Quiniou, N.; Noblet, J.; Van Milgen, J. and Dourmad, J.-Y. 1995. Effect of energy intake on performance, nutrient and tissue gain and protein and energy utilization in growing boars. Animal Science 61:133-143. https://doi.org/10.1017/ S1357729800013618

Rist, V. T. S.; Weiss, E.; Sauer, N.; Mosenthin, R. and Eklund, M. 2014. Effect of dietary protein supply originating from soybean meal or casein on the intestinal microbiota of piglets. Anaerobe 25:72-79. https://doi.org/10.1016/j. anaerobe.2013.10.003

Saraiva, A.; Donzele, J. L.; Oliveira, R. F. M.; Silva, F. C. O.; Abreu, M. L. T.; Santos, F. A. and Haese, D. 2014. Net energy for 60 to $120 \mathrm{~kg}$ pigs fed low-crude protein diets. Ciência Rural 44:1632-1638. https://doi.org/10.1590/0103-8478cr20131136

Shriver, J. A.; Carter, S. D.; Sutton, A. L.; Richert, B. T.; Senne, B. W. and Pettey, L. A. 2003. Effects of adding fiber sources to reduced-crude protein, amino acid-supplemented diets on nitrogen excretion, growth performance, and carcass traits of finishing pigs. Journal of Animal Science 81:492-502. https://doi.org/10.2527/2003.812492x

Wellock, I. J.; Fortomaris, P. D.; Houdijk, J. G. M. and Kyriazakis, I. 2006. The effect of dietary protein supply on the perfonnance and risk of post-weaning enteric disorders in newly weaned pigs. Animal Science 82:327-335. https://doi. org/10.1079/ASC200643

Yi, X. W.; Zhang, S. R.; Qiang, Y.; Yin, H. H. and Qiao, S. Y. 2010. Influence of dietary net energy content on performance of growing pigs fed low crude protein diets supplemented with crystalline amino acids. Journal of Swine Health \& Production 18:294-300. 